\title{
The Implementation of Highly Immersive Programme towards Language Proficiency of Primary School Pupils: A Literature Review
}

\author{
Nur Syahirah Abdullah, Maslawati Mohamad* \\ Faculty of Education, Universiti Kebangsaan Malaysia, Bangi, Malaysia \\ Email: *maslawati@ukm.edu.my
}

How to cite this paper: Abdullah, N. S., \& Mohamad, M. (2020). The Implementation of Highly Immersive Programme towards Language Proficiency of Primary School Pupils: A Literature Review. Creative Education, 11, 1336-1350. https://doi.org/10.4236/ce.2020.118098

Received: July 13, 2020

Accepted: August 15, 2020

Published: August 18, 2020

Copyright () 2020 by author(s) and Scientific Research Publishing Inc. This work is licensed under the Creative Commons Attribution International License (CC BY 4.0).

http://creativecommons.org/licenses/by/4.0/ (c) (i) Open Access

\begin{abstract}
Being proficient in using English language is very crucial, especially in Malaysia context as the language has been considered as a second language status. However, primary school pupils still have problems in language proficiency especially in learning English. The implementation of Highly Immersive Programme in Malaysia education system is one of the steps taken by the Ministry of Education to solve the poor language proficiency problem among the primary school pupils by involving and immersing pupils in an English environment. The aim is to ensure that pupils will have high opportunity in using the language confidently and to improve their English proficiency. Teachers are responsible for planning, developing teaching aids for the activities, and conducting English programme to motivate pupils to learn English in an effective English environment. This paper provides a literature review on the implementation of Highly Immersive Programme towards language proficiency of primary school pupils from the aspect of issue in pupils' language proficiency, the implementation of Highly Immersive Programme in school and past studies that related to this paper.
\end{abstract}

\section{Keywords}

English as Second Language (ESL), Language Proficiency, Highly Immersive Programme, English-Rich Environment

\section{Introduction}

English language is the international language used by most of the people in the world. It has been used and introduced by all the countries and has been implemented in the education system. These countries introduce this language since 
primary and preschool years (Mayo, 2017). Besides, language skills are viewed as part of human capital and play an important role in labor market performance, schooling, health care, consumption and investment (Yao, Ohinata, \& van Ours, 2016). This is significant with the aims of English Language Teaching in primary schools as stipulated in the curriculum to provide students with the basic English language skills and knowledge of grammar. This is to enable them to be competent and proficient enough in using the language in and out of school for different purposes and situations.

Malaysia education system can be divided into preschool education, primary education, secondary education, post-secondary education and tertiary education (Man et al., 2019). The approximate number of years the ordinary Malaysian who completes the formal education from preschool to tertiary levels is between 14 to 15 years of English language education (Azman, 2016). However, most of the pupils still have problem in language proficiency especially in primary school. They are still not able to master all the language skills due to some reasons. This is proven when researchers have found that second language learners have obstructions and complications in speaking English language (Nijat et al., 2019). At the same time, almost 50\% of children between 10 and 14 years old are not interested in reading (Yusof, 2010). Besides, the impact of children with low language proficiency is they have poor attention and listening skills.

According to Osada (2004) both teachers and learners have not drawn much attention to listening skills because they are generally less aware of its importance. As a result, the learners are having difficulties in comprehending the spoken texts since they have not acquired the language to receive effective language input. Furthermore, lack of English language proficiency also is one of the main causes of difficulties that ESL learners have in their writing tasks (Ghabool, Mariadass, \& Kashef, 2012). Based on these problems, Malaysia Ministry of Education came out with the idea of implementing English immersive programs in school. Not just in Malaysia, the number of foreign language programs for children mainly with English language is on the rise worldwide (Pinter, 2011). This is because, to ensure every individual is competent in using the language, there is a need to initiate a highly immersive English-rich environment in school (Jiew, 2017). This will help to enhance the language proficiency of the pupils from the early age. Besides, the reason for this rapid expansion is encapsulated in the common refrain "English opens doors" (Sayer, 2018). It is believed that the use of English Language helps to benefit a person with the better economic and greater social interactions. This is proven as English was given the status of a "language of integration into the global economy" (Tuspekova, Mustaffa, \& \& Ismail, 2020). The fact that English is used as an alternative form of communication for countries where English is not the national language cannot be denied (proficiency) (Cawagdan \& Rivera, 2018). This is significant with the aims of education in Malaysia is to produce holistic and competitive individuals who can fulfill the demand in the $21^{\text {st }}$ century learning (Jiew, 2017). 
So, in order to fulfill this, Highly Immersive Programme is introduced in all the schools in Malaysia. The objective of this programme is to expose pupils with the "English-rich" environment which significant with the aim of enhancing language proficiency among the pupils from the early age. This programme introduced under the To Uphold Malay Language and Strengthen the Command of English (MBMMBI) policy (Jiew, 2017). However, the focus is not just for enhancing the language proficiency of the pupils but at the same time, it exposed the pupils with the positive attitudes of learning English Language. As highlighted in the Malaysia Education Blueprint (MEB) 2013-2025, the programme is aligned with the student aspiration and supports the five shifts of the MEB. Firstly, it provides equal access to quality education of an international standard.

Next is to ensure every child is proficient in using Bahasa Malaysia and English Language which encouraged them to learn an additional language (Malaysia Education Blueprint 2013-2025, E-12). At the same time the aim is to inculcate good values in Malaysian (Matthew \& Yamat, 2020). It also establishes partnership with parents, community and private sector. Lastly, it empowers JPNs, PPDs and schools to customize solutions based on needs.

Based on this, the aim of MEB is for students to master bilingualism and to be globally competitive (Saminathan et al., 2020). So, the implementation of HIP helps to cater all the five shifts of the MEB as the objective of HIP is to enhance the English proficiency of students through increased exposure to the target language (Jiew, 2017). Besides, the implementation of HIP helps to develop positive attitudes towards the learning and usage of the English Language which is related with the third shift to develop values-driven Malaysians. The equal access to quality education of an international standard which is mentioned from the first shift can be achieved from the implementation of HIP. This is because, schools from the rural area and the urban areas are involved in this programme (Saminathan et al., 2020). It was also introduced and implemented in every public secondary and primary schools in Malaysia (Matthew \& Yamat, 2020). All the HIP activities are planned and conducted by the teachers and other stakeholders in, outside of the classroom and extra classes. The activities were conducted according to the level of the pupils in the school.

Furthermore, the implementation of HIP is aligned with the fourth shift of the MEB which the aim is to establish partnership with parents, community and private sector. This is because, it involves collaborations between schools and other stakeholders such as other schools, universities, non-governmental organisations and corporate bodies. Principals, teachers, students, parents and the community will have to be committed in ensuring this programme achieve its purpose (Ansawi, 2017). This is supported by Jiew (2017) where this programme allows a highly immersive language-rich environment to be developed for the students based on whole school approach that empower by School Heads, teachers, students, parents, and community as shown in Figure 1.

Figure 1 showed the roles of the stakeholders in the HIP implementation 


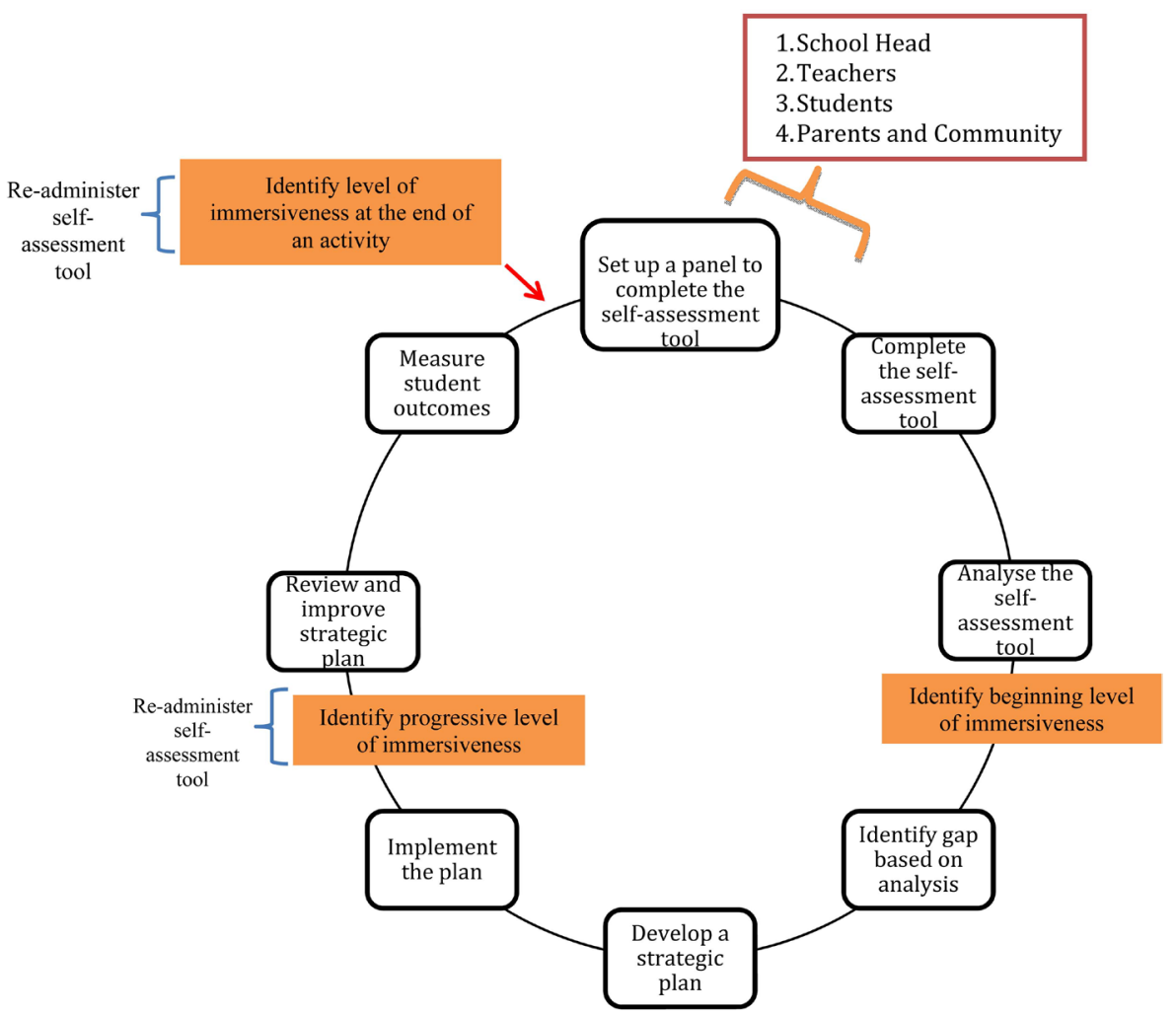

Figure 1. Source: Ministry of Education Malaysia, (2012).

cycle. All the stakeholders are given opportunities to collaborate and express their ideas in implementation of the programme. They are given the same chances and acknowledgement in fulfilling the aim of Highly Immersive programme. From this programme, it will give exposure not just for the pupils but also for other stake holders to cooperate and contribute in developing the "English-rich" environment. The School Head acts as an anchor or the leader to lead the school in actively creating a Highly Immersive English Language environment (Saminathan et al., 2020). He or she will take the responsibility to plan and organize the programmes within the school. This is to ensure that HIP activities will be conducted effectively in order to enhance the language proficiency of the pupils. At the same time, they will communicate with parents and the community, by getting them to contribute towards the implementation of HIP within the school.

Next, the English Language teacher or the educators will support the school head in creating an English rich environment. The teacher is responsible to be the role model in using the language and creates an immersive English environment for pupils by exposing them to the language and conduct effective HIP activities both in and outside the classroom. So, it is very crucial for the 21 st century teachers to acquire certain skills to manage the teaching and learning in the classrooms (Pacific Policy Research Centre, 2010). This is because, teachers need to inspire pupils' potentials, cultivate pupils' abilities and develop their creative and critical thinking skills (Saminathan et al., 2020). The English teacher will 
conduct the programme or activities that suit the needs of pupils. They will collaborate in organizing and implementing English programmes, events and activities, and they are also responsible in creating tools and aids that will be used in the HIP activities.

While the pupils are the main beneficiary of the programme or the target group to receive HIP (Saminathan et al., 2020). The pupils will be responsible on his or her personal learning process and development. The pupils will involve and participate in all the English language activities organized by the school. This process will help to develop and build their confidence in using the language and for the improvement of HIP in school. Next, they will also provide feedbacks on the HIP programs or activities conducted by the teachers. Pupils' feedback is crucial to continue and to bring improvements to HIP in the school (Saminathan et al., 2020). The next stakeholders are parents and community. They are supporters who help in contribute and creating an English environment. This is supported by Matthew and Yamat (2020) who agreed that parents can contribute by having the community to provide their expertise and assistance for the school. They will collaborate with the school heads and the teachers to support all the HIP activities organized by the school.

So it fulfills the need for ESL learners to learn through communication in different settings outside of the classroom (Saminathan et al., 2020). The pupils will be exposed with the high immerse English activities and learn the correct ways to enhance their language proficiency. They will enjoy learning English language in fun-learning activities with the co-operation from different stakeholders such as parents and community. At the same time, through this research, the teachers will learn and understand the effective methods to overcome the challenges in implementing Highly Immersive programme. So, it is very important for each of the stakeholders to play the role as the agent of knowledge.

\section{Literature Review}

\subsection{Language Proficiency}

There is a finding from a study that discovered the English proficiency is the most basic issue that can lead to the low performance of HIP implementation in school (Racha \& Yunus, 2019). Language proficiency represents the most important sign of second language skills and knowledge (Daller \& Phelan, 2013). It is one of the traits of a good language learner, which will enable the English language learners to communicate well with diverse populations around the world (Cawagdan \& Rivera, 2018). The importance of English does not affect only the exchange of information in different fields on a worldwide platform, but it also affects the livelihood and job opportunities of the fresh graduates in Malaysia (Man et al., 2019).

However, language proficiency problem has been one of the major issues that arise in our education system. For example, lack of English language proficiency being one of the main causes of difficulties that ESL learners have in their writ- 
ing tasks (Ghabool, Mariadass, \& Kashef, 2012). This is supported by Jiew (2017) who stated that there is a research done on English proficiency and reported that students still at low level of English proficiency. Lack of English language proficiency may place immigrant children at greater risk for lower levels of early literacy and school readiness (Palacious \& Kibler, 2016). One way to increase students' chances of success in English taught programs is to support growth in students' general English language proficiency (Rose et al., 2019). So, the implementation of Highly Immersive Programme is one of the good efforts done by the Ministry of Education of Malaysia in solving the language proficiency problems among the primary school pupils.

\subsection{Nature of Language Proficiency}

Daller and Phelan (2013) stated that language proficiency is the most important sign of second language skills and knowledge. This is because, a person with a good language proficiency will have the opportunity to communicate effectively with the people around the world. This is supported by Cawagdan and Rivera (2018) who agreed that having good language proficiency is one of the characteristic of a good language learner, which help the English language learners to communicate well with variety populations around the world. Bachman (1990) defines language proficiency as a language ability or ability in language used. While Farhady (1983) states that the term "proficiency" refers to the examinees' ability in a particular area of competency. This is to determine the extent to which they can function in a real language use situation.

In this context of study, language proficiency referring to the English language proficiency required by the pupils and the teachers in participating and conducting the Highly Immersive Programme in school. This is because, most of the pupils having problem in language proficiency where they cannot communicate well and express their ideas effectively when they are participating in activity that related with the second language especially English language. In the workplace context, good communication skills refer to the ability to transmit and receive information clearly (Ting et al., 2017).

However, in this context of study, teachers tend to face problems to plan the effective activity or program that can help to enhance the language proficiency of the pupils. This is due to several factors where lead to unsuccessful English language activities conducted in school. This is because, the use of language not just involved the grammatical aspects, but also the ability to apply language appropriately in variety contexts and the ability to organize one's thoughts through language (Harley et al., 1990). Stern (1983) agreed that proficiency can be looked at as a goal which can be defined in terms of objectives or standards. So, having good language proficiency is very crucial to ensure that the person can communicate well and solve problems that related to second language.

\subsection{Factors Affecting Language Proficiency}

There are many factors identified which give the big impacts on developing lan- 
guage proficiency of the primary school pupils. There are class sizes, learning and teaching resources, learning and teaching practices, motivation, pupils' education background and social background (Phon, 2017). Learning and teaching resources are very crucial to promote communicative language use which can help to enhance language proficiency. There are three kinds of teaching resources or materials which are known as text-based, task-based, and realia (Nguyen, Warren, \& Fehring, 2014). For example, the teachers can use language games, textbooks, project-based activities, and role plays to develop language proficiency of the pupils. At the same time, teachers can implement various types of activity by using the realia such as signs, magazines, and newspapers to graphic and visual sources such as maps, pictures, symbols, graphs, and charts (Richards, 2001).

Next factor that affects the language proficiency is learning and teaching practices. The most common problem faced by the English teacher is the low motivation of the pupils to participate in the learning or activity. Motivation can be defined as a basic aspect of the human mind which includes contrasting desires and rational thinking together with the cultural identity (Dornyei, 2001). This is due to the poor learning environment or atmosphere in the classes. The worst part is when some of the teachers did not use effective teaching practices that help to arouse the pupils' interest in learning. Nguyen, Warren and Fehring (2014) agreed that most of the teachers did not use songs or games to teach and entertain the pupils, which is believed to make classes happy and more relaxing, especially language classes. So, it affects the motivation of the pupils to learn and demotivate the teachers to conduct the lesson effectively.

Besides, the factor affecting language proficiency is pupils' education background and social background. These two factors are very significant in developing the language proficiency of primary school pupils effectively. Poor social background leads to low motivation in learning the language. Research studies have proved that motivation is the main factor in learning second language because it determines human behavior by energizing it and giving it direction (Dornyei, 1998). One of the most effective ways to support English language development is by safeguarding home language maintenance and growth, in addition to accelerated English language learning both in the classroom and at home (Dennaoui et al., 2015). Based on this explanation, we can conclude that the efforts not just coming from the teachers, but it also starting from home. Pupils will have high opportunity to receive a good education background if they have a good social background. Pupils' social background includes their racial origin, family income, family structure, the level of parental education and the level of students' English proficiency (Phon, 2017). Parents cannot fully depend on the teachers alone and put a high hope that the pupils to be proficient in the language by themselves. This means that it is essential for the parents to take extra efforts and play their role in motivating the pupils to learn the language and to master the skills. It is very important to equip the pupils with the positive learning environment not just in school but also at home. 
In this context of study, the implementation of Highly Immersive Programme will help to cater this issue where the parents can collaborate with the teachers in developing good language proficiency among the pupils. This is because, different stakeholders are involved in the implementation of Highly Immersive Programme at school. So, parents can express their ideas and share their opinions with the teachers in order to ensure the pupils comprehend the language and skills effectively. For example, if the parents cannot speak English language with the pupils proficiently, they can volunteer themselves by participating in every English programme conducted by the school. They can provide or donate the learning materials such as English book, magazines or newspapers to the schools. At the same time, they must ensure that the pupils constantly practicing the language skills not just at school but also at home.

As for conclusion, all these factors play an important role in developing language proficiency of primary school pupils. The efforts taken by the Ministry of Education in implementing Highly Immersive Programme at school is a very significant idea that can help to cater these factors. So, every stakeholder has to collaborate and play their role to ensure the pupils have good language proficiency which can be used not just in the classroom but also outside of the classroom.

\section{Highly Immersive Programme}

There are multiple studies that discovered on the implementation of Highly Immersive Programme towards language proficiency of primary school pupils. Phon (2017) stated there is a strong relationship between pupils English language proficiency levels and extra-curricular activities that are responsive to student need which act as a support to their learning. Besides, there is a finding from a study that stated English proficiency is the most basic issue that can lead to the low performance of HIP implementation in school (Racha \& Yunus, 2019). So, the teachers need to be creative in implementing teaching and learning strategies by providing the pupils with the positive learning environment that can help to cater their language proficiency problem. Outdoor teaching is also a recognized method for improving learning and is widely used by elementary school teachers in Taiwan (Asrial et al., 2019).

Besides, in providing highly immersive language-rich environment in school, pupils need to be exposed to the English language environment where multiple activities that have high-quality linguistic input both within and beyond the classroom. This is because, learning resources that come from outside the room can be useful for students to use and develop oral, written, and visual languages (Asrial et al., 2019). The consistency of conducting the fun English learning activities repeatedly with the effective learning resources will engage the pupils in the HIP programme. This is because, the implementation of Highly Immersive Programme able provides an English-rich environment with variety chances for exposure, experience and engagement to English (Ansawi, 2017). 


\section{The Implementation of Highly Immersive Programme in Malaysia}

Highly Immersive Programme is introduced in all the schools in Malaysia. This is one of the latest programme that had been introduced by the Ministry of Education mainly to promote active command of English among the school pupils (Racha \& Yunus, 2019). In Malaysian context, HIP was introduced in 1999 for Year 1 (7-year-old) to Form 5 (17-year-old) students (Saminathan et al., 2020). This programme introduced under the To Uphold Malay Language and Strengthen the Command of English (MBMMBI) policy (Ministry of Education, 2016). All the primary and secondary schools were required to conduct English activities for students in order to expose them with the use of English language and to increase the time to learn English in school. Unfortunately, the programme did not achieve the main objective and gradually faded (Saminathan et al., 2020).

Then, Highly Immersive Programme has been reintroduced with more strength and intensity under the existing MBMMBI policy which its pilot phase was first commenced in 2016 and eventually implemented in all schools in 2018 (Saminathan et al., 2020). Besides, HIP is a part of the English language enhancement programme as advocated in Wave 2 (2016-2020) of Malaysia's Education Blueprint (MEB) 2013-2025 (Ministry of Education, 2016). According to Jiew (2017), the objective of HIP is to improve the English proficiency of students through increased exposure to the target language. Besides that, HIP aims to inculcate positive behaviours towards the learning and usage of the English Language. The implementation of HIP helps to expose the students with the use of the English language through a variety of activities in and out of the classroom.

All the stakeholders are given opportunities to collaborate and express their ideas in implementation of the programme. This is supported by Saminathan et al. (2020) who stated that principals, teachers, students, parents and the community are involved in HIP in order to maintain the sustainability of the programme and to ensure the activities are successfully carried out in the schools. Schools will be provided with a toolkit so that they will be guided for a more purposeful planning of activities, based on their local context and capabilities. According to documents reviewed, it was found that the objectives of the Highly Immersive Programme are clear and the activities suggested are useful (Matthew \& Yamat, 2020). There will be assistance and support from district, state and national level to motivate schools to share, learn, and help each other to get the best result from implementing these activities. There are many activities that can be conducted by the teachers such as English Zone, Reading Corner, Story Telling, English language camp, English Chatting Day, Fashion Show and "Welcome Friends to School". All the activities suggested in this programme are significant and beneficial for the pupils and the teachers in learning English language in a more fun way.

The implementation of HIP will create positive atmosphere which helps to 
encourage the ESL learners to practice English in and outside of the classroom. Besides, HIP encourages students to learn through playing Saminathan et al. (2020). The impact is the students feel excited and having fun in learning and practicing English language as a medium of communication. So, the implementation of HIP creates a gratitude for the language and the students will be more comfortable to practise it in their daily lives.

\section{Positive Impacts and Challenges of Implementing HIP at School towards Language Proficiency of Primary Pupils}

\subsection{Positive Impacts}

The Highly Immersive Program creates a rich English-speaking environment where the social learning theory encompasses attention, memory and motivation of the pupils (Matthew \& Yamat, 2020). There are several studies that identified the positive impacts in implementing Highly Immersive Programme at school towards language proficiency of primary school. Ansawi (2017) stated that the introduction of Highly Immersive Programme in enhancing pupils' competences in language from 2015 triggered more positive change. For example, it helps to increase the engagement of the pupils and the teachers. This is because, the teachers and the pupils need to collaborate with their friends or cliques when they are conducting and participating in HIP activities. The teachers can share ideas and their opinions with other teachers in their school or other school. This is very crucial to ensure that the implementation of HIP activities can be conducted effectively. This is because, the peer cooperation will help to encourage the learner's capabilities to solve the task on his or her own (Ansawi, 2017).

At the same time, the teacher can have discussion with the pupils to ensure the objective of the lesson or activity will be achieved successfully. For example, when they are participating in English competition such as "Story Telling", the teacher and the pupils can exchange their ideas in designing the costume, planning the sequence of the story or do the make-up. This collaboration will provide the best result and high opportunity for the pupil to win the competition. Furthermore, the implementation of HIP helps to build good relationship among the stakeholders. This is because, all the stakeholders collaborate and exchange their ideas among themselves to find the best strategy that can be implemented in the programme. It was observed that there was an active participation and cooperation from the parents when the activities were carried out (Ansawi, 2017).

Besides, from the implementation of HIP activity, the pupils need to discuss with their friends and cooperate to solve the tasks given by the teacher. This is because, peer cooperation helps to provide the learners with more understanding on the abstract concepts with the greater consciousness (Crawford, 1996). For example, when they are participating in English immersive activity such as "Fashion Show", they must give good cooperation and exchange ideas among them. They have to plan effectively and choose the best idea in designing the 
outfits, choose the materials, and use the suitable make up for the models or their friend who represent the group. So, the discussion will increase the engagement of the pupils with their friends.

Next, the implementation of Highly Immersive Programme helps the teachers to use effective strategies to conduct meaningful activities in order to enhance the language proficiency of the pupils. This is because, there are different stakeholders involved in this programme. At the same time, there is a HIP toolkit and guidelines provided by the Ministry of Education to conduct this programme. All the stakeholders can collaborate and exchange their ideas among themselves to find the best strategy that can be implemented in the programme. Besides, they can use the HIP toolkit and the guidelines to plan for the activities that will be conducted. According to documents reviewed, it was found that the objectives of the Highly Immersive Programme are clear and the activities suggested are (Matthew \& Yamat, 2020). So, it helps the stakeholders such as School Head, teachers, pupils, parents and community to have a clear view on the programme.

So, all these efforts will help the teachers to prepare the effective materials and activities that can help to arouse the language proficiency of the pupils through the implementation of HIP activities. The varieties activities conducted provide situations for the pupils to speak in English and learn experientially.

\subsection{Challenges in Implementing HIP at School}

There is a finding from a study that discover that English proficiency is the most basic issue that can lead to the low performance of HIP implementation in school (Racha \& Yunus, 2019). This is due to the few challenges identified in implementing Highly Immersive Programme towards language proficiency of the primary school pupils. The first challenge is due to the unmanageable workload of the teachers. As we know, the role of the teachers in school not just focusing on the teaching itself, but they have to do the administrative work and they must do it almost every day especially the class teachers. Besides, they have to handle pupils with poor attitude and bad behaviour. At the same time, they have to cope with extra-curricular activities that conducted out of working hour, monitor the pupils' attendance and evaluate their homework in their free time. Multiple tasks with big roles and responsibilities at the workplace will affect the quality of work-life balance among teachers (Noor et al., 2020).

Next, they do not have enough resources or materials in the school. Language-teaching outcomes depend mainly on the use of learning and teaching materials (Harmer, 2007). Due to the location factor, some of the schools did not have efficient facilities and materials that can help them in preparing the activities. In this new era of ICT, it is essential for the school to have good facilities in order to maximize the learning process of the pupils (Racha \& Yunus, 2019). Young (2003) agreed that the use of Information and Communication Technology (ICT) give the impact on the language learning and literacy acquisition environment. So, due to the poor learning environment, it is hard for the teachers 
to plan and conduct the activity with the pupils. This kind of challenges will demotivate the teachers to plan for the effective programme that can help to cater the language proficiency of the pupils. This is because, having a good motivation is a key success to the work performance of a teacher. Motivation can be defined as a basic aspect of the human mind which includes contrasting desires and rational thinking together with the cultural identity (Dornyei, 2001).

Besides, Highly Immersive Programme was introduced to enhance the English learning process but it can be a failure too if it is not conducted with suitable materials (Racha \& Yunus, 2019). So, it is very important for the school administrators to ensure that all the learning and teaching materials are well prepared in the school. At the same time, the teachers have to find the alternative ways to solve these problems. For example, the teacher can suggest or propose the ideas in collecting fund for the English programme during Parent-Teacher Association meeting. Teachers can collaborate with the parents in preparing the learning materials or the activities such as decorating the English garden or English zone. Besides, teachers can encourage the parents who are afforded and available to donate the English learning materials such as English story book, magazines, and newspapers.

\section{Conclusion and Implication}

The findings from the previous studies on the implementation of Highly Immersive Programme towards language proficiency of primary school pupils are very crucial for the teachers in solving the issues in language proficiency among the primary school pupils. Besides, past studies discovered the nature of language proficiency, factors affecting language proficiency and the issues in the pupils' language proficiency. The positive impacts and the challenges of implementing of Highly Immersive Programme in Malaysia were also discovered in the previous studies.

However, most of the research did not provide enough information on the language proficiency from the implementation of Highly Immersive Programme towards primary school pupils in Malaysia. There are only specific language skills discovered which did not explore the language proficiency as a whole. At the same time, some of the past studies only explore the implementation of HIP towards higher level of ESL learners such as tertiary level which did not suit the level of the participants in this study. So, it is hard to find the effective teaching and learning strategies that can be implemented in Highly Immersive Programme in primary school. However, the past studies provide the research gap in the study. So, it helps the researcher to explore and discover more on the implementation of Highly Immersive Programme towards language proficiency of primary school pupils.

Based on the previous studies that discovered the implementation of HIP in Malaysia, it can be concluded that all the stakeholders such as school administrators, teachers, pupils, parents and the community need to collaborate to im- 
plement an effective HIP Programme in order to create an English-rich environment. This is aligned with the objective of Highly Immersive Programme which is to enhance pupils' English proficiency and to practice the language confidently. Besides, it has no doubt that teachers play the most crucial role in the implementation of HIP. However, the overall findings discovered from the previous studies showed that there are several factors that affect the effectiveness of the HIP implementation. So, all the stakeholders need to collaborate and find the alternative ways and the best method to solve the issues in implementing HIP.

Besides, the implication of this paper is beneficial in helping the teachers and other stakeholders to plan the effective strategy for developing language proficiency of primary school pupils. From this, all the challenges can be overcome with the effective and appropriate measurements in order to solve the issue. So, the language proficiency of primary school pupils can be developed effectively through the implementation of Highly Immersive Programme. Lastly, through this paper, it is hoped that the implementation of HIP in our education system will help to provide awareness to the pupils and develop creative and innovative ideas in order to motivate them to have high self-confidence in using English language in their daily life.

\section{Conflicts of Interest}

The authors declare no conflicts of interest regarding the publication of this paper.

\section{References}

Ansawi, B. (2017). Promoting the 3Es (Exposure, Experience, Engagement) in an English-Rich Rural Primary School Community. The English Teacher, 46, 30-42.

Asrial, A., Syahrial, S., Kurniawan, D. A., Subandiyo, M., \& Amalina, N. (2019). Exploring Obstacles in Language Learning among Prospective Primary School Teacher.

Azman, H. (2016). Implementation and Challenges of English Language Education Reform in Malaysian Primary Schools. 3L: Language, Linguistics, Literature, 22, 65-78. https://doi.org/10.17576/3L-2016-2203-05

Bachman, L. F. (1990). Fundamental Considerations in Language Testing. Oxford: Oxford University Press.

Cawagdan, H. C. C. C. C., \& Rivera, E. E. (2018). Influence of Language Learning Strategies to the English Proficiency Test Performance of College Students. JPAIR Multidisciplinary Research, 32, 149-163. https://doi.org/10.7719/jpair.v32i1.580

Crawford, K. (1996). Vygotskian Approaches to Human Development in the Information Era. Educational Studies in Mathematics, 31, 43-62. https://doi.org/10.1007/BF00143926

Daller, M. H., \& Phelan, D. (2013). Predicting International Student Study Success. Applied Linguistics Review, 4, 173-193. https://doi.org/10.1515/applirev-2013-0008

Dennaoui, K., Nicholls, R. J., O’Connor, M., Tarasuik, J., Kvalsvig, A., \& Goldfeld, S. (2015). The English Proficiency and Academic Language Skills of Australian Bilingual Children during the Primary School Years. International Journal of Speech-Language 
Pathology, 18, 157-165. https://doi.org/10.3109/17549507.2015.1060526

Dornyei, Z. (1998). Motivation in Second and Foreign Language Learning. Language Teaching, 31, 117-135. https://doi.org/10.1017/S026144480001315X

Dornyei, Z. (2001). Motivational Strategies in the Language Classroom. Cambridge: Cambridge University Press. https://doi.org/10.1017/CBO9780511667343

Farhady, H. (1983). New Directions for ESL Proficiency Testing. In J. W. Oller (Ed.), Issues in Language Testing Research (pp. 253-268). Newbury House.

Ghabool, N., Mariadass, M. E., \& Kashef, S. H. (2012). Investigating Malaysian ESL Students' Writing Problems on Conventions, Punctuation, and Language Use at Secondary School Level. Journal of Studies in Education, 2, 130-143.

https://doi.org/10.5296/jse.v2i3.1892

Harley, B., Cummins, J., Swain, M., \& Allen, P. (1990). The Nature of Language Proficiency. In B. Harley, P. Allen, J. Cummins, \& M. Swain (Eds.), The Development of Second Language Proficiency (Cambridge Applied Linguistics, pp. 7-25). Cambridge: Cambridge University Press. https://doi.org/10.1017/CBO9781139524568.003

Harmer, J. (2007). The Practice of English Language Teaching. Harlow, England: Pearson Education.

Jiew, F. F. (2017). The Evaluation of Highly Immersive Programme (HIP). International Journal of Academic Research in Business and Social Sciences, 7, 2222-6990

Kaur, N. (2006). Non-Autonomy and Low-English Proficiency among Malaysian Students: Insights from Multiple Perspectives. In M. Kamisah Ariffin, R. Ismail, N. K. Leng, \& R. A. Aziz (Eds.), English in the Malaysian Context (pp. 21-34). Shah Alam: University Publication Centre (UPENA) UiTM.

Man, C. F., May, A. L. J., Sharif, S., Singh, S., \& Singh, B. (2019). Exploring the Use of Drama-Based Activities as a Learning Tool in English Oral Proficiency Development among Students from Non-Malay-Medium Nation Schools: A Preliminary Study. International Journal of Academic Research in Business and Social Sciences, 9, 1202-1215. https://doi.org/10.6007/IJARBSS/v9-i6/6082

Matthew, V. R., \& Yamat, H. (2020). Evaluation of Highly Immersive Program (HIP) Using CIPP Model. International Journal of Academic Research in Business and Social Sciences, 10, 509-526.

Mayo, M. D. P. G. (2017). Learning Foreign Languages in Primary School: Research Insights. Bristol: Multilingual Matters.

Ministry of Education Malaysia (2012). Preliminary Report-Malaysia Education Blueprint Executive 2013-2025 Executive Summary, E-16.

Ministry of Education Malaysia (2016). The Highly Immersive Programme (HIP) English Language. Kementerian Pelajaran Malaysia.

Nguyen, H. T., Warren, W., \& Fehring, H. (2014). Factors Affecting English Language Teaching and Learning in Higher Education. English Language Teaching, 7, 94-105. https://doi.org/10.5539/elt.v7n8p94

Nijat, N., Atifnigar, H., Chandran, K., Selvan, S. L. T., \& Subramonie, V. (2019). Psychological Factors that Affect English Speaking Performance among Malaysian Primary School Pupils. American International Journal of Education and Linguistics Research, 2, 55-68. https://doi.org/10.46545/aijelr.v2i2.117

Noor, N. M., Salleh, J., Rafil, A. N. A., \& Johari, A. (2020). The Impact of Employee's Job Stress on Staff's Job Performance at Administrative Office in Bahagian Samarahan, Sarawak. Jurnal Intelek, 15, 89-97. https://doi.org/10.24191/ji.v15i1.271

Osada, N. (2004). Listening Comprehension Research: A Brief Review of the Past Thirty 
Years. Dialogue, 3, 53-66.

Pacific Policy Research Centre (2010). 21st Century Skills for Students and Teachers. Honolulu, HI: Kamehameha Schools, Research \& Evaluation Division.

Palacios, N., \& Kibler, A. (2016). Oral English Language Proficiency and Reading Mastery: The Role of Home Language and School Supports. The Journal of Educational Research, 109, 122-136. https://doi.org/10.1080/00220671.2014.927341

Phon, S. (2017). Factors Affecting the English Language Proficiency of Students Majoring in English at a Rural University in Cambodia. UC Occasional Paper Series, 1, 69-92.

Pinter, A. (2011). Children Learning Second Languages. Berlin: Springer. https://doi.org/10.1057/9780230302297

Racha, E., \& Yunus, M. M. (2019). Issues Contributing to Low Performance of Highly Immersive Programme (HIP) in a Rural National School in Song (p. 40). Kuala Lumpur: Seri Pacific Hotel.

Richards, J. C. (2001). Curriculum Development in Language Teaching. Stuttgart: Ernst Klett Sprachen. https://doi.org/10.1017/CBO9780511667220

Rose, H., Curle, S., Aizawa, I., \& Thompson, G. (2019). What Drives Success in English Medium Taught Courses? The Interplay between Language Proficiency, Academic Skills, and Motivation. Studies in Higher Education, 1-13. https://doi.org/10.1080/03075079.2019.1590690

Saminathan, C., Yin, L. P., Mustafa, Z., \& Abdullah, A. (2020). Teachers' Challenges in Implementing the Highly Immersive Programme (HIP) in the Classrooms. Learn Journal: Language Education and Acquisition Research Network, 13, 194-207.

Sayer, P. (2018). Does English Really Open Doors? Social Class and English Teaching in Public Primary Schools in Mexico. System, 73, 58-70.

https://doi.org/10.1016/j.system.2017.11.006

Stern, H. H. (1983). Fundamental Concepts of Language Teaching. Oxford: Oxford University Press.

Ting, S. H., Marzuki, E., Chuah, K. M., Misieng, J., \& Jerome, C. (2017). Employers' Views on Importance of English Proficiency and Communication Skill for Employability in Malaysia. Indonesian Journal of Applied Linguistics, 7, 315-327.

https://doi.org/10.17509/ijal.v7i2.8132

Tuspekova, A., Mustaffa, R., \& Ismail, K. (2020). Understanding English Speaking Practice in Public Schools in Kazakhstan: A Case Study in Almaty. 3L: The Southeast Asian Journal of English Language Studies, 26, 171-185. https://doi.org/10.17576/3L-2020-2601-12

Yao, Y., Ohinata, A., \& van Ours, J. C. (2016). The Educational Consequences of Language Proficiency for Young Children. Economics of Education Review, 54, 1-15. https://doi.org/10.1016/j.econedurev.2016.05.008

Young, S. S. C. (2003). Integrating ICT into Second Language Education in a Vocational High School. Journal of Computer Assisted Learning, 19, 447-461. https://doi.org/10.1046/j.0266-4909.2003.00049.x

Yusof, N. M. (2010). Influence of Family Factors on Reading Habits and Interest among Level 2 Pupils in National Primary Schools in Malaysia. Procedia-Social and Behavioral Sciences, 5, 1160-1165. https://doi.org/10.1016/j.sbspro.2010.07.253 